\title{
Glucose Required for Tissue Formation and Its Effects on Cane Yield, Recoverable Sugar, and Sugar Yield
}

\author{
Nunik Eka Diana (D), Supriyadi (D), Djumali (D), Budi Santoso (D), Anik Herwati (D), \\ Sri Yulaikah (D), Supriyono (D), Ruly Hamida (D), Aprilia Ridhawati, and Abdurrakhman
}

\begin{abstract}
The Indonesian Sweeteners and Fiber Crops Research Institute, Jl. Raya Karangploso Km. 4 Kotak Pos 199, Malang 65152, Indonesia
\end{abstract}

Correspondence should be addressed to Nunik Eka Diana; nekadk@yahoo.com

Received 26 October 2020; Revised 6 November 2020; Accepted 13 November 2020; Published 29 November 2020

Academic Editor: Vera Popovic

\begin{abstract}
Copyright (c) 2020 Nunik Eka Diana et al. This is an open access article distributed under the Creative Commons Attribution License, which permits unrestricted use, distribution, and reproduction in any medium, provided the original work is properly cited.
\end{abstract}

\begin{abstract}
Glucose in sugarcane affected cane yield, recoverable sugar, and sugar yield. Glucose is available since the formation of the stems and stored until sugarcane is ready to be harvested. Information regarding the need for glucose to form sugarcane plant tissue is still not widely available. So, research was conducted to determine the quantity of glucose to form sugarcane plant tissue and its relation to cane yield, recoverable sugar, and sugar yield obtained. The research was carried out at the Karangploso Research Station and Laboratory of Plant Chemistry, Indonesian Sweeteners and Fiber Crops Research Institute, in July 2016-September 2017. A split plot design with two factors and three replications was utilized. The main factor was the growth phases, namely, the vegetative phase and maturity phase, while the other factor was sugarcane varieties, namely, PS-881 (early mature), JR-01 (earlymiddle mature), Kenthung (early-middle mature), and Bululawang (middle-late mature). The measurements of nitrogen, carbon, and the ash content of the leaves and stems were at 5 months (representing the growth period) and 9 months (representing the ripening period). The results showed that quantities of $1.962-2.160 \mathrm{~kg}$ and $2.066-2.113 \mathrm{~kg}$ glucose were required to form each $\mathrm{kg}$ of leaf and stem tissue depending on the growth phase and variety. Glucose requirements in the maturing phase affected the cane yield, recoverable sugar, and sugar yield as much as by $51.48 \%, 57.60 \%$, and $58.26 \%$, respectively.
\end{abstract}

\section{Introduction}

The Indonesian sugar production was 2.212 million tonnes in 2017, while the projected national sugar consumption demand would be 2.825 million tonnes in 2019 so that the shortfall needs to be imported. The sugar production needs to be increased to achieve self-sufficiency of household sugar demand.

The production can be obtained by increasing the productivity of cane yield and sucrose content as well. Cane yield is cumulative of glucose available for stem growth during the formation of the stem until the stem is harvested [14]. The sugar yield is the result of the accumulation of sucrose deposits in the stem during the ripening phase to harvest [8]. Glucose is derived from the results of daily photosynthesis after being reduced by the process of respiration maintenance [15].
Glucose produced by daily photosynthesis is used for respiration maintenance, and the rest is used for growth and storage [10]. Glucose for growth is partitioned into roots, stems, and leaves. Glucose that enters the root and leaf organs is used to form root and leaf tissue [6]. Glucose that goes into the stem is used to form stem tissues during the growth phase and used for glucose stem reserve during the ripening phase [21]. Each sugarcane variety requires different amounts of glucose to form root, stem, and leaf tissues depending on the organic compounds that make it up [13]. The varieties that need high glucose to form plant tissue will produce lower plant growth than those that require low glucose. Until now, there is not much information about the amount of glucose required to form $1.0 \mathrm{~kg}$ of plant organ tissue for each sugarcane variety. The research hypothesis was the varieties requiring high glucose to form plant tissues 
will produce low cane yield; therefore, the sugar yield will also be low. The main aim of this research was to find out the value of the quantity of glucose required to form a sugarcane plant tissue and its relation to cane yield, recoverable sugar, and sugar yield.

\section{Materials and Methods}

Research has been conducted at the Karangploso Research Station and the Laboratory of Plant Chemistry, Indonesian Sweeteners and Fiber Crops Research Institute, in July 2016-September 2017.

The treatment was arranged in a split plot design with 3 replications. The main plot was growth phases, namely, the vegetative growth phase (age: 5 months after planting) and the maturing phase ( 9 months after planting). The subplot was sugarcane varieties, namely, PS-881 (early mature sugarcane), JR-01, Kenthung (early-middle mature sugarcane), and Bululawang (middle-late mature sugarcane). Each plot consisted of five $10 \mathrm{~m}$ rows with $110 \mathrm{~cm}$ apart. Besides growth and maturing phase, observations were also made during the production phase when the plants were harvested (12 months after planting). Observation of production parameters include cane yield, recoverable sugar, and sugar yield. Cane yield is measured by weighing the harvested stems per plot. Recoverable sugar is measured by taking samples of harvested stems, milking them, and measuring brix and pol from the extracted liquid. The sugar yield is calculated based on the cane yield and recoverable sugar obtained.

Sampling was started 5 months after planting (representing the growth period) and 9 months after planting (representing the maturing period). Six plant samples were taken from each plot and separated between stems and leaves, and then they were dried and powdered. The powders were analysed for ash, nitrogen, and carbon content. Ash content $(\mathrm{A})$ was quantified with the ashing method using a muffle oven (furnace) at an initial temperature $250^{\circ} \mathrm{C}$ for 1 hour and continued to $600^{\circ} \mathrm{C}$ for 2 hours. Nitrogen $(\mathrm{N})$ content was analysed using the Kjeldahl method, and carbon content (C) was analysed using the Walkley-Black method.

Glucose required for growth (CRG) and $\mathrm{CO}_{2}$ produced during growth $(\mathrm{CPG})$ are calculated by the equation given by Vertregt and Penning de Vries [17]:

$$
\begin{aligned}
& \mathrm{CRG}=((5.39 \mathrm{C}+0.80 \mathrm{~A}+5.64 \mathrm{~N}-1191) 1.053) / 1000 \\
& \left(\mathrm{~kg} \mathrm{~kg}^{-1}\right) \text {, } \\
& \mathrm{CPG}=(4.24 \mathrm{C}+1.17 \mathrm{~A}+8.28 \mathrm{~N}-1744+77.7 \mathrm{CRG}) \\
& \text { /1000( kg. kg-1 }{ }^{-1} \text {, }
\end{aligned}
$$

where $\mathrm{C}$ is the carbon content ( $\left.\mathrm{g} \cdot \mathrm{kg}^{-1}\right), \mathrm{A}$ is the ash content $\left(\mathrm{g} \cdot \mathrm{kg}^{-1}\right)$, and $\mathrm{N}$ is the nitrogen content $\left(\mathrm{g} \cdot \mathrm{kg}^{-1}\right)$.

\section{Results and Discussion}

3.1. Cane Yield, Recoverable Sugar, and Sugar Yield. Sugarcane yield, recoverable sugar, and sugar yield were influenced by the varieties used (Table 1). JR-01 variety produced the highest cane and recoverable sugar so that the sugar yield was the highest. The Bululawang cane yield was not different from PS-881 and Kenthung, but recoverable sugar was the lowest so that the sugar yield was the lowest.

In this research, the relationship between sugar yield and recoverable sugar (RS) and cane yield (CY) was calculated with sugar $=0.9205 \mathrm{RS}+0.9311 \mathrm{CY}-0.8552$ with a correlation coefficient $(r)$ of 1.00 . These results mean that $100 \%$ of the sugar yield was determined by the recoverable sugar and cane yield. The effect of recoverable sugar and productivity on the sugar yield was $49.13 \%$ and $50.87 \%$, respectively. Thus, the two components have the same strong influence in determining the sugar yield.

\subsection{Glucose Required to Form Tissues and Carbon Dioxide} Released. Glucose required to form tissue (leaves and stems) and carbon dioxide released during the process of tissue formation were influenced by the growth phase, sugarcane variety, and the interaction of both (Tables 2 and 3).

Stepwise regression analysis showed that the effects of N, $\mathrm{C}$, and ash content on leaf tissue formation during the fastgrowing phase were $31.58 \%, 39.18 \%$, and $29.24 \%$, respectively, and $100 \%$ in total. Additionally, the N, C, and ash effects were $24.89 \%, 40.52 \%$, and $34.48 \%$, respectively, and $99.9 \%$ in total. The influence of $\mathrm{N}, \mathrm{C}$, and ash content during the fast-growing phase on the stem was $18.66 \%, 46.94 \%$, and $34.40 \%$, while during the maturing phase, it was $16.57 \%$, $60.59 \%$, and $22.83 \%$, respectively. The effect of $\mathrm{N}$ levels on glucose requirement was higher during the fast-growing phase than the maturing phase.

The energy conversion through growth respiration was measured from the amount of $\mathrm{CO}_{2}$ released during tissue formation. It was influenced by the growth phase, the variety, and the interactions of both (Table 3).

The influences of variety, growth phase, and their interaction on $\mathrm{CO}_{2}$ released were similar to the effect on glucose requirements. The relationship between required glucose for leaves (GL) and $\mathrm{CO}_{2}$ released was $\mathrm{GL}=0.7128$ $\mathrm{CO}_{2}+0.2917(r=0.984)$ for the fast-growing phase and $\mathrm{GL}=0.7046 \mathrm{CO}_{2}+0.2959(r=0.989)$ for the maturing phase. The relationship between required glucose for stems (GS) and $\mathrm{CO}_{2}$ released was $\mathrm{GS}=0.4970 \mathrm{CO}_{2}+0.5005$, with a correlation coefficient $(r)$ of 0.957 for the fast-growing phase and $\mathrm{GS}=0.5118 \mathrm{CO}_{2}+0.4857$ with a correlation coefficient (r) of 0.975 for the maturing phase.

\section{Discussion}

Table 1 shows that sugar yield was influenced by productivity and recoverable sugar. Variety had specific characteristics that influenced productivity and recoverable sugar also. This statement was supported by Supriyadi et al. [16] and Djumali et al. [3] who showed the effects of sugarcane varieties on productivity, recoverable sugar, and sugar yield. Then, Gomathi et al. [6] stated the sugar yield illustrates the yield of sucrose obtained per unit area of land. Recoverable sugar and cane yield are the two main components that make up sugar productivity $[2,9]$. 
TABLE 1: Cane weight, recoverable sugar, and sugar yield of sugarcane varieties.

\begin{tabular}{lccc}
\hline Variety & Cane weight $(\mathrm{kg})$ & Recoverable sugar $(\%)$ & ${\text { Sugar yield }\left(\mathrm{kg}^{-s t e m}{ }^{-1}\right)}$ \\
\hline PS-881 & $1.565 \mathrm{~b}$ & $10.605 \mathrm{~b}$ & $0.1659 \mathrm{~b}$ \\
JR-01 & $1.722 \mathrm{a}$ & $11.404 \mathrm{a}$ & $0.1964 \mathrm{a}$ \\
Kenthung & $1.557 \mathrm{~b}$ & $10.538 \mathrm{~b}$ & $0.1640 \mathrm{~b}$ \\
Bululawang & $1.499 \mathrm{~b}$ & $9.956 \mathrm{c}$ & $0.1491 \mathrm{c}$ \\
DMRT 5\% & 0.110 & 0.433 & 0.0116 \\
\hline
\end{tabular}

The numbers accompanied by the same letter in one column mean that they are not significantly different in Duncan's multiple range test levels of $5 \%$.

TABLE 2: Glucose requirements during the fast-growth and maturing phase.

\begin{tabular}{|c|c|c|c|c|c|c|}
\hline \multirow{2}{*}{ Variety } & \multicolumn{3}{|c|}{ Glucose required to form the leaf tissue $\left(\mathrm{kg} \cdot \mathrm{kg}^{-1}\right)$} & \multicolumn{3}{|c|}{ Glucose required to form the stem tissue $\left(\mathrm{kg} \cdot \mathrm{kg}^{-1}\right)$} \\
\hline & Fast growth & Maturing & Average & Fast growth & Maturing & Average \\
\hline PS-881 & $2,086 \mathrm{c}$ & $1,965 \mathrm{e}$ & $2,026 \mathrm{Q}$ & $2,108 \mathrm{a}$ & 2,108 a & $2,108 \mathrm{P}$ \\
\hline JR-01 & $2,094 \mathrm{c}$ & $1,962 \mathrm{e}$ & $2,028 \mathrm{Q}$ & $2,090 \mathrm{c}$ & $2,070 \mathrm{~d}$ & $2,080 \mathrm{R}$ \\
\hline Kenthung & $2,133 \mathrm{~b}$ & $1,996 \mathrm{~d}$ & $2,064 \mathrm{P}$ & $2,103 \mathrm{ab}$ & $2,093 \mathrm{bc}$ & $2,098 \mathrm{Q}$ \\
\hline Bululawang & $2,160 \mathrm{a}$ & $1,990 \mathrm{~d}$ & $2,075 \mathrm{P}$ & $2,113 \mathrm{a}$ & $2,066 \mathrm{~d}$ & $2,090 \mathrm{Q}$ \\
\hline Average & $2,118 \mathrm{X}$ & $1,978 \mathrm{Y}$ & & $2,104 \mathrm{X}$ & $2,084 \mathrm{Y}$ & \\
\hline
\end{tabular}

The numbers accompanied by the same lowercase letters and the numbers accompanied by the same uppercase letters in the same column or row mean that they are not significantly different in Duncan's multiple range test levels of 5\%.

TABLE 3: Carbon dioxide released during the leaf and stem tissue formations on the fast-growing and maturing phases.

\begin{tabular}{lccccc}
\hline \multirow{2}{*}{ Variety } & \multicolumn{2}{c}{$\mathrm{CO}_{2}$ during leaf tissue formation $\left(\mathrm{kg}^{\left.-\mathrm{kg}^{-1}\right)}\right.$} & \multicolumn{2}{c}{$\mathrm{CO}_{2}$ during stem tissue formation $\left(\mathrm{kg}^{\left.-\mathrm{kg}^{-1}\right)}\right.$} \\
& Fast growth & Maturing & Average & Fast growth & Maturing \\
\hline PS-881 & $0,989 \mathrm{c}$ & $0,903 \mathrm{e}$ & $0,946 \mathrm{R}$ & $0,966 \mathrm{a}$ & $0,952 \mathrm{~b}$ \\
JR-01 & $0,994 \mathrm{c}$ & $0,904 \mathrm{e}$ & $0,949 \mathrm{R}$ & $0,924 \mathrm{~d}$ & $0,959 \mathrm{P}$ \\
Kenthung & $1,010 \mathrm{~b}$ & $0,915 \mathrm{~d}$ & $0,962 \mathrm{Q}$ & $0,947 \mathrm{bc}$ & $0,940 \mathrm{c}$ \\
Bululawang & $1,040 \mathrm{a}$ & $0,920 \mathrm{~d}$ & $0,980 \mathrm{P}$ & $0,948 \mathrm{~b}$ & $0,927 \mathrm{~S}$ \\
\hline Average & $1,008 \mathrm{X}$ & $0,910 \mathrm{Y}$ & & $0,944 \mathrm{Q}$ & $0,927 \mathrm{~d}$ \\
\hline
\end{tabular}

The numbers accompanied by the same lowercase letters and the numbers accompanied by the same uppercase letters in the same column or row mean that they are not significantly different in Duncan's multiple range test levels of 5\%.

The sugar yield is the result of the accumulation of glucose saved in the stem during the ripening phase till harvest. Glucose is obtained from the daily results of photosynthesis after being reduced to the needs of the respiration process. Glucose required to form leaf and stem tissues during the rapid growth phase was greater than during the maturing phase. According to Penning de Vries et al. [13], plant tissue (leaves, stems, roots, flowers, fruits, and seeds) is composed of carbohydrates, proteins, fats, lignins, organic acids, and minerals in different compositions. It was further explained that the formation of every $\mathrm{kg}$ of carbohydrates, protein, fat, and organic acids required as much as $1.275 \mathrm{~kg}, 1.887,3.189 \mathrm{~kg}, 2.231,0.954 \mathrm{~kg}$ of glucose, respectively. During the fast-growth phase, more glucose from photosynthesis is used for the formation of leaf, stem, and root tissue, whereas during the maturing phase, it is mostly used for carbohydrate storage [18]. Therefore, more glucose is required to form leaf and stem tissues during the fast-growth phase than during the maturing phase.

Consequently, glucose required to form leaf and stem tissues during the fast-growing phase is higher than the maturing phase. He et al. [7] reported that leaf and stem tissues containing high $\mathrm{N}$ nutrients require high glucose levels to form these tissues. According to Pawirosemadi [12], $\mathrm{N}$ nutrient needs in the vegetative phase are more than in the maturing phase. Furthermore, Fortes et al. [4] and Yong et al. [19] stated that $\mathrm{N}$ nutrient is a constituent of protein compounds, and protein is the most important component in the growth phase.

Bululawang required the most glucose to form leaf tissue during the fast-growing phase, while Kenthung and Bululawang required the most during the maturing phase. PS- 881 and Bululawang required the most glucose to form stem tissue during the fast-growth phase, and PS-881 required the most during the maturing phase. This is thought to be caused by protein compounds formed in these tissues more than the other varieties, thus requiring a higher amount of glucose. According to Darmawan and Baharsyah [1], glucose required to form tissue is partly converted into energy and partly for the preparation of organic compounds. These results mean that the more the leaf tissue is formed, the higher the rate of growth respiration is. According to Zhao et al. [20] and Miri et al. [11], the faster the growth rate of a plant tissue, the faster the rate of growth respiration.

4.1. Relationship of Glucose Requirement with Cane Yield, Recoverable Sugar, and Sugar Yield. The cane yield (CY) and glucose required to form leaves during the fast-growth phase (GLG) and maturing (GLM), as well as glucose required to 
form the stem during the fast-growth phase (GSG) and the maturing phase (GSM), had the correlation coefficient $(r)$ same as that without GLM which is equal to 0.959. GLM did not affect cane yield because without GLM, the total effect did not change that is equal to $95.9 \%$. Thus, the equation is CY $=-1.9053$ GLG -1.8952 GSG - 6.0153 GSM + 10.5335. This equation shows that the three contents of glucose required (GLG, GSG, and GSM) have a negative effect on cane yield. According to Glassop et al. [5], when glucose available for growth was not different, the higher glucose for tissue formation, the lower the weight of the tissue formed so that the lower the cane yield. The multiple linear regression analysis using a step back showed the total effect was 95.9\% which consisted of the influence of GLG at $34.24 \%$, GSG at $10.18 \%$, and GSM at $51.48 \%$. Thus, the greatest effect on cane yield is GSM followed by GLG and finally GSG.

The correlation coefficient $(r)$ between cane yield and GLG, GSG, GLM, and GSM was 0.722, and it was the same as the correlation coefficient of the relationship between recoverable sugar and GSG, GLM, and GSM. These results mean that GLG has no role in influencing yield with a total effect of $72.2 \%$. Thus, the equation obtained is recoverable sugar $\quad(\mathrm{RS})=-1.5138 \quad$ GSG $-0.9678 \quad$ GLM -5.5729 GSM +8.8306 . Further analysis with a step back obtained information that the total effect of $72.2 \%$ consists of $12.92 \%$ of the influence of GSG, $1.68 \%$ of the influence of GLM, and $57.60 \%$ of the influence of GSM. Thus, the greatest influence on yield is GSM followed by GSG and finally GLM, in which all of these had negative effects. According to Pawirosemadi [12], tissue formation which required a great amount of glucose showed its meristematic state; thus, the new tissues of the stem are still being formed. In such conditions, available stem glucose is partitioned to new tissues and stored carbohydrates. The high glucose requirement for stem tissue formation reduced glucose available for stored carbohydrates which leads to a decrease in recoverable sugar.

The relationship between sugar yield (SY) and GLG, GSG, GLM, and GSM was SY = - 1.7655 GLG - 3.3186 GSG - 0.9435 GLM - 10.6760 GSM + 17.2278 $(r=0.910)$. It means that the four contents of glucose required (GLG, GSG, GLM, and GSM) affect the sugar yield with a total effect of $91.0 \%$. Further analysis obtained information that the total influence of $91.0 \%$ consists of the influence of GLG at $29.01 \%$, GSG at $0.69 \%$, GLM at $3.50 \%$, and GSM at $58.26 \%$. Thus, the greatest influence was GSM followed by GLG GLM, and finally GSG. These results occur as a result of the effect of productivity and recoverable sugar which are equally strong on sugar yield.

4.2. Implications of Research Results. Each $\mathrm{kg}$ of sugarcane stem tissue requires $2.066-2.160 \mathrm{~kg}$ of glucose, while for leaf tissue, $1.962-2.113 \mathrm{~kg}$ glucose is required. When the stem and the leaf weight are proportional, each $\mathrm{kg}$ of sugarcane stem requires $4.028-4.273 \mathrm{~kg}$ of glucose. Stem weight is the main component in sugarcane productivity besides the number of stems per hectare. Therefore, increasing productivity can be achieved with a high photosynthetic rate and a low maintenance respiration rate of varieties so that glucose is available for the fast-growth phase of the plant.
All glucose required to form plant tissues affect negatively the cane yield, recoverable sugar, and sugar yield. Thus, recoverable sugar and sugar yield can be increased by selecting a variety with a low glucose tissue formation requirement. Agronomic practices may trigger the protein formation such as excessive nitrogen fertilizer which causes a high glucose requirement for tissue formation and reduces cane yield, sugar recovery, and sugar yield.

Glucose requirement for the stem tissue maturing phase is the most dominant factor in influencing cane yield, sugar recovery, and sugar yield with a magnitude of each effect of $51.48,57.60$, and 58.26\%. According to the results, cultivation practices or environment conditions triggered by unnecessary formation of new stem tissue in the maturing phase should be avoided.

During the maturing phase, glucose available for stem growth is mainly used for carbohydrate storage as sucrose. This high sucrose concentration inactivates auxins and cytokines and hinders growth. Auxin or cytokine will be reactivated in the presence of water. Therefore, precipitation or irrigation during the maturing phase is likely to activate these hormones, and reserved sucrose will be translocated to the meristem tissue and converted into new stem and leaf tissues such as the growth of side shoots and sucker. This causes productivity, recoverable sugar, and sugar yield to decrease. Therefore, it is necessary to avoid the application of cultivation techniques that trigger the formation of new stem tissue during the maturing phase. Therefore, the glucose requirements for the leaf and stem tissue formations were $1.962-2.113 \mathrm{~kg}$ and $2.066-2.160 \mathrm{~kg}$, respectively, which depends on the growth phase and variety. These requirements had negative effects on cane yield, recoverable sugar, and sugar yield. The effects for stem formation on the maturing phase were more dominant in cane yield, recoverable sugar, and sugar yield as much as by 51.48, 57.60, and 58.26\%, respectively.

\section{Conclusions}

Glucose requirements for the leaf and stem tissue formations were $1.962-2.113 \mathrm{~kg}$ and $2.066-2.160 \mathrm{~kg}$, respectively, which depend on the growth phase and variety. These requirements had negative effects on cane yield, recoverable sugar, and sugar yield. The effects for stem formation on the maturing phase were more dominant in cane yield, recoverable sugar, and sugar yield as much as by 51.48, 57.60, and 58.26\%, respectively.

\section{Abbreviations}

CY: $\quad$ Cane yield

GL: $\quad$ Glucose for leaves

GLG: Glucose leaf growth

GLM: Glucose leaf maturity

GS: $\quad$ Glucose for stems

GSG: Glucose stem growth

GSM: Glucose stem maturity

SY: Sugar yield. 


\section{Data Availability}

All the data used to support the findings of this study are included within this manuscript.

\section{Conflicts of Interest}

The authors declare that there are no conflicts of interest regarding the publication of this paper.

\section{Authors' Contributions}

All the authors contributed equally to this research and drafting this manuscript.

\section{Acknowledgments}

The authors would like to thank the Head of the Sweetener and Fiber Crops Research Institute for funding this research through DIPA in 2016-2017. Their thanks go to Mr. Bambang Heliyanto, Mr. Nur Asbani, and Mr. Lestari who have guided them in the preparation of this manuscript. They also thank the Head of Karangploso Gardens and their staff and all those who have helped in carrying out this research activity.

\section{References}

[1] J. Darmawan and J. S. Baharsyah, Dasar-Dasar Fisiologi Tanaman, SITC, Jakarta, Indonesia, 2010.

[2] P. Dashora, "Productivity and sustainability of sugar (Saccharum officinarum) genotypes under planting seasons and fertility levels in south-east Rajasthan," Academia Arena, vol. 4, no. 1, pp. 37-41, 2012.

[3] B. Djumali, B. Heliyanto, and A. D. Khuluq, "Evaluasiklonklontebu potensial di lahan kering," Indonesian Journal of Agronomy, vol. 46, no. 3, pp. 328-336, 2018.

[4] C. Fortes, P. C. O. Trivelin, A. C. Vitti, R. Otto, H. C. J. Franco, and C. E. Faroni, "Stalk and sucrose yield in response to nitrogen fertilization of sugarcane under reduced tillage," Pesquisa Agropecuária Brasileira, vol. 48, no. 1, pp. 88-96, 2013.

[5] D. Glassop, U. Roessner, A. Bacic, and G. D. Bonnett, "Changes in the sugarcane metabolome with stem development. Are they related to sucrose accumulation?" Plant and Cell Physiology, vol. 48, no. 4, pp. 573-584, 2007.

[6] R. Gomathi, P. N. G. Rao, P. Rakkiyappan, B. P. Sundara, and S. Shiyamala, "Physiological studies on ratoonability of sugarcane varieties under tropical indian condition," American Journal of Plant Sciences, vol. 4, no. 2, pp. 274-281, 2013.

[7] M. He, K. Zhang, H. Tan et al., "Nutrient levels within leaves, stems, and roots of the xeric species Reaumuria soongorica in relation to geographical, climatic, and soil conditions," Ecology and Evolution, vol. 5, no. 7, pp. 1494-1503, 2015.

[8] M. R. Jones, A. Singels, and N. G. Inman-Banber, "Simulating source and sink control of structural growth and development and sugar accumulation in sugarcane," Proceedings of South Africa Sugarcane Technology Association, vol. 84, pp. 157-163, 2011.

[9] S. Junejo, G. M. Kaloi, R. N. Panhwar et al., "Performance of newly developed sugarcane genotypes for some qualitative an quantitative traits under thatta conditions," Journal of Animal \& Plant Sciences, vol. 20, no. 1, pp. 40-43, 2010.
[10] F. R. Marin, J. W. Jones, F. Royce et al., "Parameterization and evaluation of predictions of DSSAT/CANEGRO for Brazilian sugarcane," Agronomy Journal, vol. 103, no. 2, pp. 304-315, 2011.

[11] H. R. Miri, A. Rastegar, and A. R. Bagheri, "The impact of elevated $\mathrm{CO}_{2}$ on growth and competitiveness of $\mathrm{C} 3$ and $\mathrm{C} 4$ crops and weeds," European Journal of Experimental Biology, vol. 2, no. 4, pp. 1144-1150, 2012.

[12] M. Pawirosemadi, Dasar-dasar Teknologi Budidaya Tebu Dan Pengolahan Hasilnya, UM Press, Ann Arbor, Michigan, 2011.

[13] F. W. T. Penning deVries, D. M. Jansen, F. H. M. tenBerge, and A. Bakema, Simulation of Ecophysiological Processes of Growth in Several Annual Crops. Simulation Monograph 29, Pudoc, Wageningen, Netherlands, 1989.

[14] M. d. A. Silva, J. L. Jifon, C. M. d. Santos, C. J. Jadoski, and J. A. G. d. Silva, "Photosynthetic capacity and water use efficiency in sugarcane genotypes subject to water deficit during early growth phase," Brazilian Archives of Biology and Technology, vol. 56, no. 5, pp. 735-748, 2013.

[15] N. A. Streck, J. G. Hanauer, L. F. Gabriel, T. C. Buske, and J. A. Langner, "Leaf development and growth of selected sugarcane clones in a subtropical environment," Pesquisa Agropecuária Brasileira, vol. 45, no. 10, pp. 1049-1057, 2010.

[16] A. Supriyadi, A. D. Khuluq, and D. Djumali, "Pertumbuhan, produktivitas dan hasil hablur klon tebu masak awal-tengah di tanah inceptisol," Jurnal Agronomi Indonesia, vol. 46, no. 2, pp. 208-214, 2018.

[17] N. Vertregt and F. W. T. Penning de Vries, "A rapid method for determining the efficiency of biosynthesis of plant biomass," Journal of Theoretical Biology, vol. 128, no. 1, pp. 109-119, 1987.

[18] J. Wong, S. Nayak, K. Koch, and R. Ming, "Carbon partitioning in sugarcane (Saccharum species)," Frontiers in Plant Science, vol. 4, no. 201, pp. 1-6, 2013.

[19] Y. Yong, S. Gao, Y. Jiang et al., "The physiological and agronomic responses to nitrogen dosage in different sugarcane varieties," Front Plant Sciences, vol. 10, no. 406, pp. 1-18, 2019.

[20] X. Zhao, S.-H. Zheng, F. Fatichin, A. Suzuki, and S. Arima, "Varietal difference in nitrogen redistribution from leaves and its contribution to seed yield in soybean," Plant Production Science, vol. 17, no. 1, pp. 103-108, 2014.

[21] D. Zhao, B. Glaz, M. S. Irey, and C.-J. Hu, "Sugarcane genotype variation in leaf photosynthesis properties and yield as affected by mill mud application," Agronomy Journal, vol. 107, no. 2, pp. 506-514, 2015 